\title{
DIFFERENCES BETWEEN THE SPECTRA OF RESPIRATORY ILLNESSES IN CHILDREN LIVING IN URBAN AND RURAL ENVIRONMENTS
}

\author{
Miroslav Dostál ${ }^{1}$, Miroslav Průcha ${ }^{2}$, Eva Rychlíková ${ }^{3}$, Anna Pastorková ${ }^{1}$, Radim J. Šrám ${ }^{1}$ \\ ${ }^{1}$ Institute of Experimental Medicine AS CR, Prague, Czech Republic \\ ${ }^{2} \mathrm{Na}$ Homolce Hospital, Prague, Czech Republic \\ ${ }^{3}$ Public Health Institute in Ústí nad Labem, Czech Republic
}

\begin{abstract}
SUMMARY
A longitudinal study launched in 1994 within the framework of the Teplice Programme aimed at comparing the respiratory morbidity in children born (1994-1998) and living in the districts of Teplice (TE) and Prachatice (PRA) in the Czech Republic. Lists of all illnesses of 960 children from birth to 10 years of age were obtained from paediatric medical records. From 26,471 diagnoses (in ICD-10 codes), 34.7\% were diagnoses of upper respiratory infections (URI, J00-02, J06), 11.3\% of tonsillitis, $10.2 \%$ of influenza, $9.4 \%$ of bronchitis, $8.9 \%$ of laryngitis/tracheitis (J04), 2.7\% of otitis media, and $0.5 \%$ of pneumonia. The more polluted district of Teplice was divided into two parts: the town itself (TE-town) and the rest of the district (TE-district). The cumulative incidence rates of the above respiratory illnesses per 100 children per 10 years were 2,212 in TE-town, 2,192 in PRA and 1,985 in TE-district. In the first two years of life, the children from TE-town had a significantly higher incidence of laryngitis/tracheitis, influenza, otitis media, and pneumonia and significantly lower incidence of bronchitis and tonsillitis than children living in PRA. The incidence rates of laryngitis/tracheitis and influenza in TE-town persisted as the highest among the three regions till the age of 10 years. The incidence rates of bronchitis (from the 1st to 5th year) and URI (from 4th to 10th year) were highest in children living in PRA. When compared to TE-town, children in TE-district had a higher incidence of upper respiratory infections (1-8 years) and lower incidence of bronchitis (6-8 years). Children in the district of Prachatice had a significantly higher prevalence of allergic rhinitis and a lower prevalence of wheezing than children in the district of Teplice. Thus, the three regions differed by the spectra of respiratory illnesses rather than by overall morbidity and, hypothetically, the effects of air pollution were obscurred by differences in the degree of urbanization.
\end{abstract}

Key words: children, respiratory morbidity, incidence, allergic rhinitis

Address for correspondence: M. Dostál, Institute of Experimental Medicine AS CR, Vídeňská 1083, 14220 Praha 4, Czech Republic. E-mail: dostal@biomed.cas.cz

\section{INTRODUCTION}

It is generally agreed that children represent a sensitive subset of the human population. As organisms in a rapid stage of growth and development, they may be more susceptible to the adverse health effects of environmental exposures, and owing to behavioural and pharmacokinetic differences they may have higher levels of exposure and retention of environmental contaminants (1). A large number of studies and research projects have been concerned with the environment and the health of children. The present paper is a short overview of a Czech epidemiological observational study that began in 1994. Its purpose was to determine whether children born and growing up in two districts of the Czech Republic, in rural, industrial and urban environments and with higher and lower concentrations of ambient air pollutants, showed evidence of measurable differences in childhood morbidity. A series of studies was performed within the framework of the Teplice Programme (2,3), named after the polluted district of Teplice in the north of the Czech Republic. The district of Prachatice in South Bohemia served as a rural control. Higher ambient concentrations of polycyclic aromatic hydrocarbons (PAHs) and particulate matter $\leq 2.5 \mu \mathrm{g} / \mathrm{m}^{3}\left(\mathrm{PM}_{2.5}\right)$ during pregnancy were associated with changes in the distribution of major lymphocyte subsets and of immunoglobulin IgE concentrations in cord blood collected at birth (4-6). Analyses of respiratory morbidity in early childhood (up to the age of 4.5 years) showed that the incidence rates of bronchitis increased as the average ambient concentrations of PAHs or $\mathrm{PM}_{2.5}$ over the previous 7 days rose (7). Other results have shown that children under 3 years of age living in households using coal for heating had increased risk of lower respiratory infections (8). Also, polymorphisms of genes coding the metabolism of xenobiotics and polymorphisms of mitochondrial DNA have been shown to influence respiratory morbidity of children (9-11). However, the overall respiratory health of children living in differently polluted environments was compared only in 462 children in the first 3 years of life (12). In the present paper we address the original hypothesis of the Teplice project, i.e., that there was a higher respiratory morbidity in children born and living in the more polluted industrial district of Teplice than in the less polluted rural district of Prachatice. Our conclusions are based on the medical records of 960 children followed from birth to the age of 10 years. 


\section{MATERIALS AND METHODS}

\section{Study Regions}

The Teplice district is situated in the northwest of the Czech Republic in a basin between the North-Bohemian Highland and the Ore Mountains. Under specific meteorological conditions (thermal inversions) that occur throughout the year, high concentrations of pollutants can occur that originate from both local and distant sources. In the district itself there are at least two large and several medium-sized combustion sources (power plants, heating plants, porcelain factories and glassworks). Other sources of pollution are strip mines and coal used to heat homes. The less polluted rural district of Prachatice with heating plants and farms as point sources of air pollution is situated in the southwest of the Czech Republic. Measurements of pollutants were performed at two monitoring sites located in the "capital" towns of each district. The highest annual mean concentration of benzo[a]pyrene in Teplice was $3.6 \mathrm{ng} / \mathrm{m}^{3}$ in 1993, which decreased to $0.75 \mathrm{ng} /$ $\mathrm{m}^{3}$ in 2009. The mean concentrations of benzo[a]pyrene in the district of Teplice were 0.3 to $0.7 \mathrm{ng} / \mathrm{m}^{3}$ higher than in the district of Prachatice in most years (except 1996). However, in 2007 the yearly means in Prachatice started to rise again. The annual mean concentrations of $\mathrm{PM}_{2.5}$ were always higher in the Teplice district, and in both districts they decreased from $61 \mu \mathrm{g} / \mathrm{m}^{3}$ and $32 \mu \mathrm{g} /$ $\mathrm{m}^{3}$ in 1993 to $22 \mu \mathrm{g} / \mathrm{m}^{3}$ and $11.5 \mu \mathrm{g} / \mathrm{m}^{3}$ in 1999 in Teplice and Prachatice, respectively. Subsequently, they started to rise again, and in 2009 after a kind of "oscillation" they were $31.2 \mu \mathrm{g} / \mathrm{m}^{3}$ in Teplice and $28.5 \mu \mathrm{g} / \mathrm{m}^{3}$ in Prachatice. The daily concentrations of $\mathrm{PM}_{10}$ were closely correlated with the concentrations of $\mathrm{PM}_{2.5}$. The annual concentrations of $\mathrm{NO}_{2}$ were stable over the years when the children were followed, being higher in Teplice (annual means ranged from 30.4 to $37.1 \mu \mathrm{g} / \mathrm{m}^{3}$ ) than in Prachatice (the means ranged from 13.1 to $16.7 \mu \mathrm{g} / \mathrm{m}^{3}$ ). A decrease of $\mathrm{NO}_{2}$ levels in Teplice after 2006 to $20 \mu \mathrm{g} / \mathrm{m}^{3}$ was due to moving the monitoring station from the town centre to the periphery. In Teplice, there was a steep decrease of $\mathrm{SO}_{2}$ concentration from $50 \mu \mathrm{g} / \mathrm{m}^{3}$ in 1994 to $12 \mu \mathrm{g} / \mathrm{m}^{3}$ in 1999 and $\mathrm{SO}_{2}$ concentrations stayed at this level till 2009; the $\mathrm{SO}_{2}$ levels in Prachatice were even lower.

The districts of Teplice and Prachatice also differ in terms of area, land use and the number of inhabitants. At the time of our study, the district of Teplice had 127,500 inhabitants and an area of $469 \mathrm{~km}^{2}$ (37\% woods, 18\% agricultural land); the district of Prachatice had 51,500 inhabitants and an area of $1,375 \mathrm{~km}^{2}(52 \%$ woods, 36\% agricultural land). The number of inhabitants of the town of Teplice was about the same as that of the entire district of Prachatice. The density of inhabitants of the town of Teplice was $2140 / \mathrm{km}^{2}$ and that of the town of Prachatice was $300 / \mathrm{km}^{2}$.

\section{Birth Cohorts and Follow-up Studies}

From May 1994 through March 1999, women who gave birth in the districts of Teplice or Prachatice were asked to participate in the "Pregnancy Outcome Study" (2, 3). Of about 8,500 births in the two districts during the study period, nurses at maternity hospitals recruited 7,502 mothers who gave birth to single infants. A stratified random sample of 1,492 mother-infant pairs, i.e., 20\% of all deliveries in the Pregnancy Outcome Study, was recruited into the Immune Biomarker Study, and samples of maternal and cord blood were collected at delivery. All pre-term and low birth weight infants as well as a systematic random sample of other births were enrolled in the study. In the Czech Republic, this study was approved by the Institutional Review Boards of the Regional Institute of Hygiene of Central Bohemia and of the Institute of Experimental Medicine, the Academy of Sciences of the Czech Republic (AS CR). A detailed description of the birth cohorts in both districts has been published elsewhere (7). Briefly, the children from the Immune Biomarker Study were contacted by paediatric nurses for follow up at the age of 3 years (children born in 1994-1996) or at 4.5 years (children born in 1997 and 1998). All paediatricians in both districts took part in the research. Paediatricians and paediatric nurses administered the questionnaires to the family and abstracted the children's medical records. Paediatric medical records were abstracted to compile a list of all illnesses suffered by each child since birth, including hospitalizations, in ICD-10 codes (the International Classification of Diseases, 10th revision). The abstracted diagnoses were divided into broader groups. The dates of office/doctor/clinic visits or hospitalizations served as a proxy for the date of illness occurrence. Only the first visits related to each illness were considered. In 2005, the medical records of children up to the age of 6 years were abstracted for acute illnesses, allergic diseases and the results of skin tests. At this time only 1,007 children continued in the study, because some families moved out of the districts and two paediatricians discontinued their participation in the study. No family refused to continue the follow up. The study continued each year until the children born in 1998 reached the age of 10 years. A further 47 children were lost to follow up owing to moving out of the districts. Thus, the data covering the period from birth to 10 years of age are available for 960 children, i.e., 245 boys and 269 girls in the Teplice district and 227 boys and 219 girls in the Prachatice district.

In this report we focus on respiratory infections. Using the codes of ICD-10, these infections are: acute laryngitis and tracheitis (LT, J04 and J05), acute bronchitis (J20, J21 and J40), pneumonia (J12, J14-16, and J18), influenza (J10, J11), otitis media (OM, H65-67, and H92), tonsillitis (J03), and upper respiratory infections (URI). The group of URI consists of acute nasopharyngitis (J00), acute sinusitis (J01), acute pharyngitis (J02), and upper respiratory infections of multiple and unspecified locations (J06). For the analysis described in this report, we did not differentiate between illnesses treated at paediatric offices and those requiring hospitalization. We graphically present the incidence for each year and the cumulative incidence for three age categories: from birth to 2 years of age ( $0-2 \mathrm{y})$, the preschool age from 2 to 6 years of age (2-6 y), and the school age from 6 to 10 years of age (6-10 y). Since we found that the geographic distribution of childhood morbidity in the district of Teplice was not homogeneous, we divided the district into two parts: the town of Teplice (TE-town), and the rest of the district (TE-district). The prevalence of allergic diseases in children of the Czech ethnicum aged 6 years was compared between the whole districts.

\section{Statistics}

The Kruskal-Wallis equality-of-populations rank test was used for bivariate analyses. Given that the frequencies of most illnesses in individual children were extremely variable, negative 
binomial regression, suitable for overspread variables (13), was used for multivariate analyses of the associations of the regions of residence with the incidence rates of respiratory illnesses. The significance of associations was determined by the rate ratio (RR), statistically significant probability and a $95 \%$ confidence interval not including the value 1 . Confounders were determined by changes in the regression coefficient of more than $15 \%$ after removal of the variable. Logistic regression was used to compare the prevalence of allergic diseases. All tests were performed using STATA 12 software.

\section{RESULTS}

\section{Respiratory Morbidity}

Yearly Incidence. In the first 10 years of life, in our cohort of 960 children, the paediatricians registered 26,471 episodes of acute illness. The following respiratory infections represented $77.6 \%$ of the total diagnoses. The illnesses diagnosed most frequently were URI (34.7\%), tonsillitis (11.4\%), influenza (10.2\%), bronchitis (9.4\%), and laryngitis and tracheitis (8.9\%). OM was reported as $2.7 \%$ and pneumonia as $0.45 \%$ of all illness episodes. The yearly incidence rates (per 100 children/year) of URI, bronchitis, LT, and influenza stratified by the area of residence are presented in Fig. 1-4. The incidence of URI in both parts of the district of Teplice was the highest in the 1st year and then it almost linearly decreased with age, being significantly

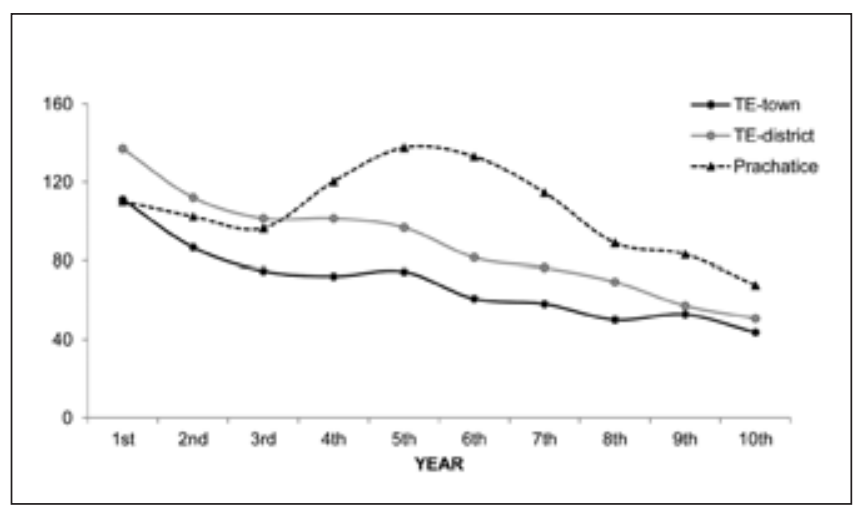

Fig. 1. Upper respiratory infections.

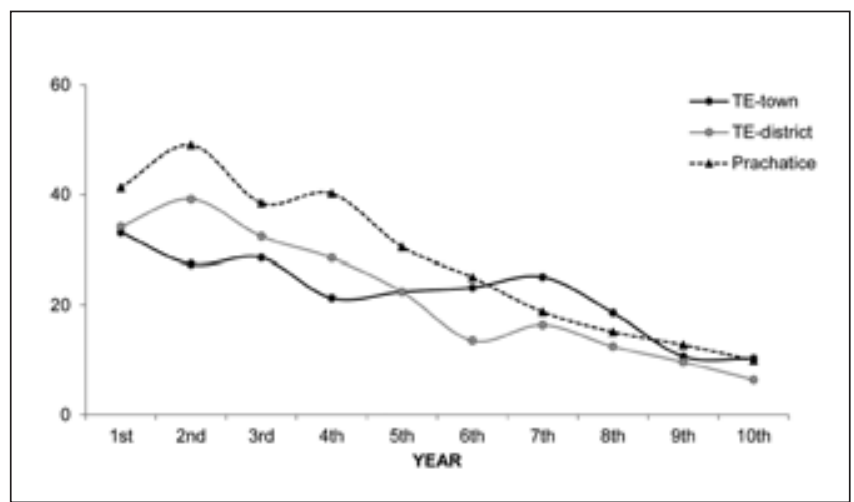

Fig. 2. Acute bronchitis.

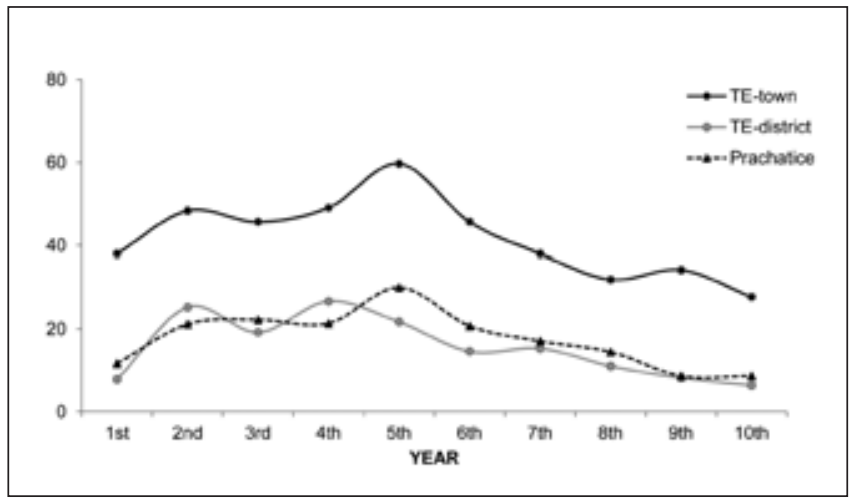

Fig. 3. Acute laryngitis and tracheitis.

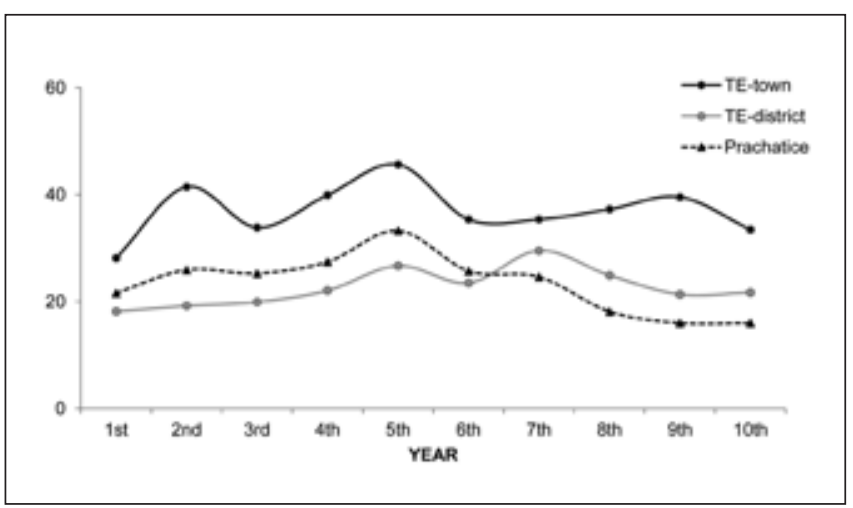

Fig. 4. Influenza.

Table 1. Cumulative incidence rates of respiratory illnesses per 100 children. Numbers of children: Teplice-town 242; Teplicedistrict 272; Prachatice 446; total per 10 years: Teplice-town 2,212, Teplice-district 1,985, Prachatice 2,192

\begin{tabular}{|l|c|c|c|c|c|c|c|c|c|}
\hline Age & \multicolumn{3}{|c|}{ 0 to 2 years of age } & \multicolumn{3}{c|}{ 2 to 6 years of age } & \multicolumn{3}{c|}{ 6 to 10 years of age } \\
\hline Residence & TE-town & TE-distr. & PRA & TE-town & TE-distr. & PRA & TE-town & TE-distr. & PRA \\
\hline Upper respiratory infections & 212.4 & 253.6 & 220.6 & 293.4 & 405.1 & 506.5 & 221.9 & 263.6 & 368.4 \\
\hline Bronchitis & 64.5 & 76.8 & 93.7 & 102.5 & 101.1 & 139.2 & 70.2 & 46.3 & 58.7 \\
\hline Laryngitis and tracheitis & 92.0 & 35.7 & 34.1 & 212.4 & 89.3 & 98.0 & 138.4 & 46.7 & 50.7 \\
\hline Influenza & 71.9 & 41.9 & 49.3 & 162 & 100.7 & 115.9 & 153.3 & 104.8 & 77.8 \\
\hline Pneumonia & 7.9 & 4.4 & 2.5 & 7.9 & 5.5 & 4.5 & 2.5 & 1.5 & 2.9 \\
\hline Otitis media & 40.1 & 34.2 & 16.1 & 38.56 & 26.8 & 32.7 & 12.8 & 11.8 & 18.2 \\
\hline Tonsillitis & 38.4 & 59.6 & 60.1 & 140.9 & 156.3 & 137.9 & 127.7 & 119.5 & 104.3 \\
\hline Total & 527.2 & 506.2 & 476.4 & 957.7 & 884.8 & 1034.7 & 726.8 & 594.2 & 681.0 \\
\hline
\end{tabular}


Table 2. Rate ratio (RR) Teplice-town/Prachatice. $\mathrm{Cl}-$ confidence interval, NS $-p>0.05$, NT - not tested. Negative binomial regression, $N=921$

\begin{tabular}{|l|c|c|c|c|c|c|c|c|c|}
\hline Age & \multicolumn{3}{|c|}{$\mathbf{0}$ to 2 years of age } & \multicolumn{2}{c|}{2 to 6 years of age } & \multicolumn{3}{c|}{6 to 10 years of age } \\
\hline & RR & $\mathbf{p}$ & $\mathbf{9 5 \%} \mathbf{C l}$ & $\mathbf{R R}$ & $\mathbf{p}$ & $\mathbf{9 5 \%} \mathrm{Cl}$ & $\mathbf{R R}$ & $\mathbf{p}$ & $\mathbf{9 5 \%} \mathrm{Cl}$ \\
\hline Upper respiratory infections & - & $\mathrm{NS}$ & - & 0.6 & $<0.001$ & $0.5-0.7$ & 0.6 & $<0.001$ & $0.5-0.7$ \\
\hline Bronchitis & 0.6 & $<0.001$ & $0.5-0.8$ & 0.7 & 0.002 & $0.6-0.9$ & - & $\mathrm{NS}$ & - \\
\hline Laryngitis and tracheitis & 2.5 & $<0.001$ & $1.9-3.3$ & 2.0 & 0.002 & $1.5-2.5$ & 2.3 & 0.002 & $1.7-3.0$ \\
\hline Influenza & 1.4 & 0.024 & $1.04-1.8$ & 1.4 & 0.011 & $1.1-1.8$ & 1.7 & $<0.001$ & $1.3-2.2$ \\
\hline Pneumonia & 2.9 & 0.038 & $1.06-7.8$ & - & NT & - & - & NT & - \\
\hline Otitis media & 2.3 & $<0.001$ & $1.7-4.1$ & - & NS & - & - & NS & - \\
\hline Tonsillitis & 0.7 & 0.002 & $0.5-0.9$ & - & NS & - & - & NS & - \\
\hline
\end{tabular}

All models were adjusted for gender, ethnicity, maternal age and education, the two parts of the study (at 3 and 4.5 years), season of birth, maternal history of allergy, preterm birth and/or low birth weight, and atopic dermatitis of children. The models for morbidity of preschool and school children were adjusted also for allergic rhinitis and wheezing.

higher in TE-district than in TE-town in the youngest and preschool children (Fig. 1). The incidence rate of URI in the PRA children increased from the 3rd year to a peak in the 5th year, while from the 4th year it was higher than in both TE-town and TE-district. Bronchitis had the highest incidence rate in the 2nd year in PRA and then decreased more or less evenly (Fig. 2). In the first 5 years it was distinctly higher in PRA than in TE-town. LT peaked in the 5th (PRA, TE-town) or 4th (TE-district) year and then decreased to the values seen in the 1st year, always being more than twice as high in the children living in TE-town than in the other two regions (Fig. 3). Influenza occurred in all 10 years more frequently in TE-town than in either TE-district or PRA (Fig. 4). The incidence of influenza in PRA was moderately higher until the 5 th year and moderately lower from the 7 th year than in TE-district. Pneumonia had the highest incidence rate in the first 3 years in TE-town and then decreased. The annual incidence oscillated owing to the low frequency of the illness (lower than 1 per 100 children). The pattern of the incidence rate of otitis media differed among the areas of residence. Children in TE-town had the highest incidence of OM in the 1st year, followed by a decrease to a plateau from the 2nd to 4th year and by a further decrease to the age of 10 years. The incidence of OM in TE-district decreased steadily from the 1st to 4th year, while it was at about the same low level in all ten years in PRA. The incidence of tonsillitis in TE-district and PRA was the lowest in the 1st year; it doubled in the 2nd year and stayed about the same till the 6th year. The increase in the incidence rate of tonsillitis with age in TE-town was significantly slower, reaching the level of the other two regions in the 4th year of life.

\section{Covariates Associated with Respiratory Morbidity}

The rate ratios of the incidence of respiratory illnesses were determined using multivariate negative binomial regression. The covariates obtained by maternal questionnaires were listed by Hertz-Picciotto et al. (7). In the present analysis we have excluded the "indoor" variables such as the type of flat, heating, smoking of mothers and other adults in the household, and having older siblings. The reason for this exclusion was that the maternal questionnaires were obtained at two ages ( 3 and 4.5 years) and the information was not checked and updated during the followup at school age. We also did not use birth weight, breast feeding and day care attendance because we did not expect they would influence the morbidity of school children. As recommended by Greenland (14), we have screened the omitted variables to see if they are not confounders. Into all models we have included the following variables: gender, ethnicity, maternal age and education, part of the study: 1st questionnaires at 3 years, 2nd questionnaires at 4.5 years of age, season of birth, maternal history of allergy, preterm birth and/or low birth weight, and atopic eczema of the children. The multivariate models for the morbidity of preschool and school children were also adjusted for allergic rhinitis and wheezing. Ethnicity, gender, maternal education, wheezing, and allergic rhinitis were the covariates most frequently associated

Table 3. Rate ratio $(R R)$ Teplice-town/Teplice-district. $\mathrm{Cl}$ - confidence interval, NS - p $>0.05, N T-$ not tested. Negative binomial regression, $N=921$

\begin{tabular}{|l|c|c|c|c|c|c|c|c|c|}
\hline \multirow{2}{*}{ Age } & \multicolumn{3}{|c|}{$\mathbf{0}$ to 2 years of age } & \multicolumn{2}{c|}{2 to 6 years of age } & \multicolumn{3}{c|}{6 to 10 years of age } \\
\hline & $\mathbf{R R}$ & $\mathbf{p}$ & $\mathbf{9 5 \%} \mathbf{C l}$ & $\mathbf{R R}$ & $\mathbf{p}$ & $\mathbf{9 5 \%} \mathrm{Cl}$ & $\mathbf{R R}$ & $\mathbf{p}$ & $\mathbf{9 5 \%} \mathrm{Cl}$ \\
\hline Upper respiratory infections & 0.8 & 0.043 & $0.7-0.99$ & 0.8 & $<0.001$ & $0.6-0.9$ & - & $\mathrm{NS}$ & - \\
\hline Bronchitis & - & NS & - & - & NS & - & 1.6 & 0.004 & $1.2-2.2$ \\
\hline Laryngitis and tracheitis & 2.4 & $<0.001$ & $1.8-3.2$ & 2.4 & $<0.001$ & $1.8-3.1$ & 2.9 & $<0.001$ & $2.2-4.0$ \\
\hline Influenza & 1.8 & $<0.001$ & $1.3-2.4$ & 1.7 & $<0.001$ & $1.3-2.2$ & 1.5 & 0.006 & $1.1-1.9$ \\
\hline Pneumonia & -- & NS & - & - & NT & - & - & NT & - \\
\hline Otitis media & -- & NS & - & - & NS & - & - & NS & - \\
\hline Tonsillitis & 0.7 & 0.005 & $0.5-0.9$ & - & NS & - & - & NS & - \\
\hline
\end{tabular}

All models were adjusted for gender, ethnicity, maternal age and education, the two parts of the study (at 3 and 4.5 years), season of birth, maternal history of allergy, preterm birth and/or low birth weight, and atopic dermatitis of children. The models for morbidity of preschool and school children were adjusted also for allergic rhinitis and wheezing. 
Table 4. Rate ratio (RR) Teplice-district/Prachatice. $\mathrm{Cl}$ - confidence interval, NS - $p>0.05, N T$ - not tested. Negative binomial regression, $N=921$

\begin{tabular}{|l|c|c|c|c|c|c|c|c|c|}
\hline Age & \multicolumn{3}{|c|}{0 to 2 years of age } & \multicolumn{3}{c|}{2 to 6 years of age } & \multicolumn{3}{c|}{6 to 10 years of age } \\
\hline & RR & $\mathbf{p}$ & $95 \%$ Cl & RR & $\mathbf{p}$ & $95 \%$ I & RR & p & $95 \%$ Cl \\
\hline Upper respiratory infections & - & NS & - & 0.8 & $<0.001$ & $0.7-0.9$ & 0.6 & $<0.001$ & $0.5-0.8$ \\
\hline Bronchitis & 0.7 & 0.002 & $0.6-0.9$ & 0.7 & 0.002 & $0.6-0.9$ & 0.7 & 0.035 & $0.5-0.98$ \\
\hline Laryngitis and tracheitis & - & NS & - & - & NS & - & - & NS & - \\
\hline Influenza & - & NS & - & - & NS & - & - & NS & - \\
\hline Pneumonia & - & NS & - & - & NT & - & - & NT & - \\
\hline Otitis media & 2.0 & $<0.001$ & $1.3-3.1$ & - & NS & - & - & NS & - \\
\hline Tonsillitis & - & NS & - & 1.2 & 0.034 & $1.01-1.5$ & - & NS & - \\
\hline
\end{tabular}

All models were adjusted for gender, ethnicity, maternal age and education, the two parts of the study (at 3 and 4.5 years), season of birth, maternal history of allergy, preterm birth and/or low birth weight, and atopic dermatitis of children. The models for morbidity of preschool and school children were adjusted also for allergic rhinitis and wheezing.

Table 5. The prevalence of allergies at the age of 6 years in children of the Czech ethnicity in the districts of Teplice and Prachatice and positivity of skin tests. (TE - district of Teplice, PRA - district of Prachatice, *number of children with skin tests). NS - nonsignificant, NT - not tested

\begin{tabular}{|l|c|c|c|c|c|c|c|c|}
\hline \multirow{2}{*}{ District } & \multicolumn{2}{|c|}{ Teplice N=466 } & \multicolumn{2}{c|}{ Prachatice N=455 } & \multicolumn{3}{c|}{ Logistic regression } \\
\hline & $\mathbf{N}$ & $\%$ & $\mathbf{N}$ & $\%$ & Ratio & OR & $\mathbf{p}$ & $\mathbf{9 5 \%} \mathrm{Cl}$ \\
\hline Wheezing (WH] & 41 & 8,8 & 23 & 5.1 & TE/PRA & 2.0 & 0.019 & $1.1-3.4$ \\
\hline Allergic rhinitis (AR) & 33 & 7.1 & 71 & 15.6 & PRA/TE & 2.7 & 0.001 & $1.7-4.2$ \\
\hline Atopic dermatitis & 44 & 9.4 & 38 & 8.4 & PRA/TE & - & NS & - \\
\hline Positive skin tests in WH & $28 / 37^{*}$ & 75.7 & $19(21)$ & 90.1 & - & - & NT & - \\
\hline Positive skin tests in AR & $24 / 27^{*}$ & 88.9 & $53(61)$ & 86.9 & - & - & NT & - \\
\hline
\end{tabular}

The logistic regression models were adjusted for categorical covariates gender, part of the study, low birth weight $(<2,500 \mathrm{~g})$ and/or gestation $<37$ weeks, maternal education, maternal allergy, an older sibling with allergy, and breastfeeding.

with the incidence of respiratory illnesses. However, none of these variables confounded the associations of the region of residence with the incidence rates of respiratory illnesses.

\section{Rate Ratios}

Cumulative incidence rates in the three age categories and three regions are presented in Table 1. The rate ratios (RR) of respiratory illnesses between the three regions of residence are given in Tables 2-4. They confirm the highest incidence rates of LT and influenza in TE-town in all three age categories. Simultaneously, the children in TE-town had a lower rate ratio of URI at preschool (2-6 y) and school age (6-10 y) than the children in PRA. The same was true for bronchitis in the age categories $0-2$ y and 2-6 $\mathrm{y}$. Also, the differences between the incidence rates of $\mathrm{OM}$ and pneumonia in the age category $0-2$ y were significant (Table 2 ). We did not find any multivariate model with a satisfactory goodness of fit for preschool and school age because of the low incidences of pneumonia. RRs Teplice-town/Teplice-district are listed in Table 3 and RRs Teplice-district/Prachatice in Table 4.

\section{Spectra of Respiratory Morbidity}

To compare the overall respiratory morbidity between the three regions of residence we used the relative frequencies of particular illnesses per 100 children, i.e., the percentages from the total of diagnoses of all seven respiratory illnesses. Such comparisons are facillated by the fact that the total occurrence of respiratory illnesses was similar in all three residence regions. The frequency of
URI in TE-town was remarkably lower that in both TE-district and PRA(Fig. 5). A plot of the relative occurrences of other respiratory illnesses (Fig. 6) shows that the lower total percentage of URI in TE-town (17\%) was accompanied by about the same magnitude increase in the relative frequency of LT and influenza. The above differences between the respiratory morbidity spectra suggest that children living in the urban environment suffered more frequently from clinically more serious illnesses than children living in the rural environment of the cleaner district of Prachatice, where $50 \%$ of respiratory illnesses were upper respiratory infections J00-02 and J06. However, with regard to the rather vague ICD code J06 and to the fact that we do not have any information on the severity and progress of particular illnesses, it is difficult to compare their burden.

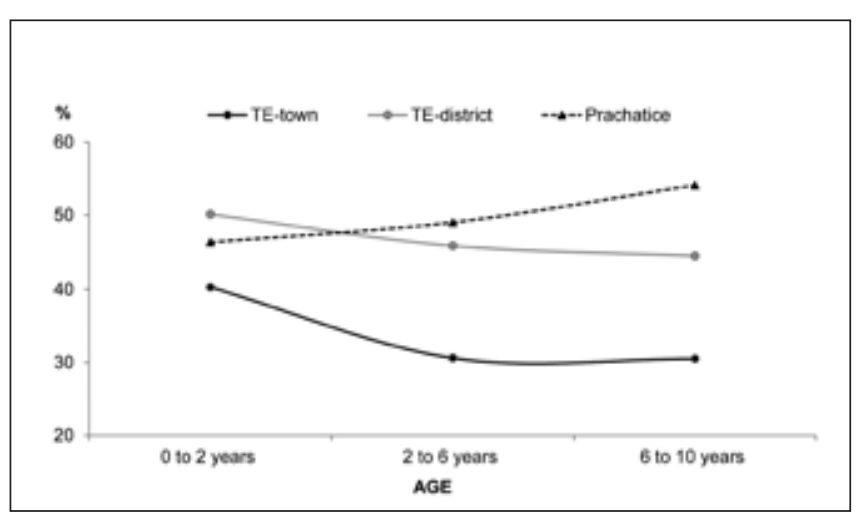

Fig. 5. URI - relative frequencies in 10 years. 


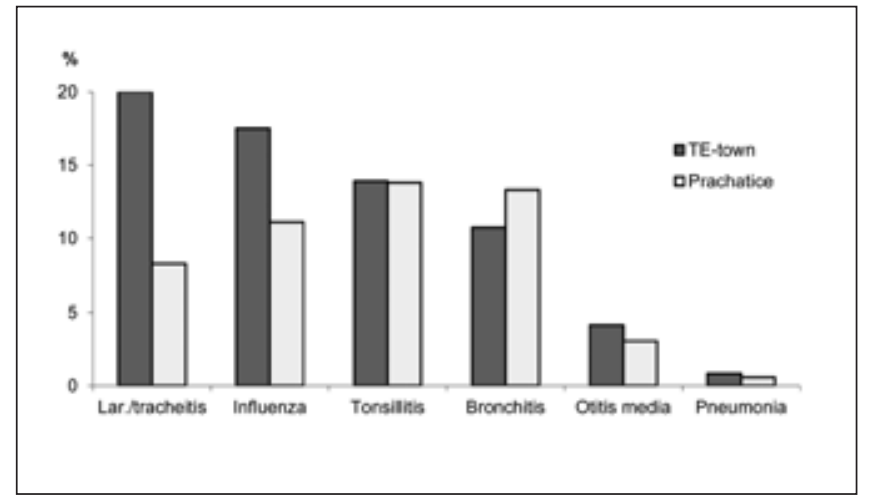

Fig. 6. Relative frequencies in 10 years.

\section{Prevalence of Allergic Diseases}

The data on allergies in children at the age of 6 years were obtained in 2005. There were no new reported cases of allergies in the age 6-10 years. Allergies occurred extremely rarely in Roma children. Out of 65 Roma children in the present study, only 2 children were diagnosed with allergic rhinitis and one child with wheezing. Another child experienced a drug allergy (15). Out of 921 children of Czech ethnicity 64 (6.9\%) children had wheezing, 104 (11.3\%) children were diagnosed with allergic rhinitis (J30.9 - Allergic rhinitis, unspecified) and 82 (8.9\%) children with atopic dermatitis (L20.9 - Atopic dermatitis, unspecified). Allergic reactions to drugs were reported by paediatricians in 32 $(3.5 \%)$ children and food allergies in $13(1.4 \%)$ children. The prevalence of allergies as well as positive reactions to inhalant allergens as determined by skin tests did not differ between TEtown and TE-district; therefore, we compared the whole district of Teplice with the district of Prachatice (Table 5). The prevalence of wheezing in children of Czech ethnicity was $8.8 \%$ in the district of Teplice and $5.1 \%$ in the district of Prachatice. The odds ratio (OR) Teplice/Prachatice was 1.99 ( $\mathrm{p}=0.019,95 \%$ CI 1.1-3.4). The prevalence of atopic dermatitis did not differ between the districts (9.4\% and 8.4\%). Allergic rhinitis was diagnosed significantly more frequently in the district of Prachatice (15.9\%) than in the district of Teplice (7.0\%). The OR Prachatice/Teplice of allergic rhinitis was $2.7(\mathrm{p}<0.001,95 \%$ CI 1.7-4.2), and selfreported maternal allergy had OR $1.9(\mathrm{p}=0.007,95 \%$ CI $1.2-3.1)$. Numbers of children with skin tests are given in Table 5. The children with allergic rhinitis in the district of Prachatice had the highest proportion of positivity to pollen (42 children out of 61 tested), while children with wheezing in Teplice had the highest proportion of positivity to mites and/or home dust (17 children out of 37 tested).

\section{DISCUSSION}

The major aim of this study was to compare the morbidity of children living in the district of Teplice with the morbidity of children living in the district of Prachatice, i.e., in two districts differing in the extent of environmental pollution. In the course of the study we found that the morbidity of children living in the town of Teplice (urban environment) differed from the morbidity of children living in the other parts of the district (smaller towns, industrial environment). No such differences were noted in the
Prachatice district with a rural environment and smaller towns the largest of them is the town of Prachatice with about 11,500 inhabitants. The children in TE-town had the highest incidence rates of pneumonia and $\mathrm{OM}$ in the age category $0-2 \mathrm{y}$, and in all ten years olds the highest incidence rates of LT and influenza. On the other hand, the children living in the district of Prachatice had the highest incidence rate of URI from the 4th to the 10th year of age, and in the first 5 years the highest incidence rate of bronchitis. In TE-district, similarly to children in PRA, the youngest and preschool children suffered less frequently from laryngitis/tracheitis and influenza and more frequently from URI than children in TE-town. The incidence rates of illnesses showed a decreasing trend from the age of 2 years (bronchitis, OM, pneumonia, URI) or 5 years (LT), although the trend was not identical in all three regions. At the age of 10 years there were no major differences between the incidence rates of URI, bronchitis, OM, tonsillitis, and pneumonia in children residing in the different districts/regions.

The highest incidence of laryngitis/tracheitis was found in children living in the town of Teplice. The ICD-10 codes used by paediatricians were: J04 - Acute laryngitis and tracheitis $(\mathrm{N}=396)$, J04.0 - Acute laryngitis $(\mathrm{N}=529)$, J04.1 - Acute tracheitis $(\mathrm{N}=1195), \mathrm{J} 04.2$ - Acute laryngotracheitis $(\mathrm{N}=770), \mathrm{J} 05$ - Acute obstructive laryngitis (croup) and epiglottis $(\mathrm{N}=3)$. In the literature, this group of diseases is also called pseudocroup or subeppiglotic laryngotracheitis and also croup (7), based on a survey of the diagnostic approaches of the paediatricians taking part in the present study. Most cases in our study occurred in autumn in all residential regions. The results of studies on the association of air pollution with the occurrence of pseudocroup are contradictory. There were no associations of LT with the levels of $\mathrm{SO}_{2}, \mathrm{NO}_{2}$ or dust in children in Southern Bavaria (16). Severien and Mietens reported that although the number of hospitalizations of children with stenosing laryngitis slightly correlated with the level of $\mathrm{NO}_{2}$, in a long-term study there was no association between the levels of $\mathrm{NO}_{2}$ and croup (Bochum, Germany) (17). Rebmann et al. analyzed the effects of $\mathrm{SO}_{2}, \mathrm{NO}, \mathrm{NO}_{2}, \mathrm{CO}$, ozone and dust on croup frequency in a region characterized by medium- and small-sized towns and rural areas and concluded that at the concentrations of pollutants observed, they represented only a weak additional factor to individual and familial disposition and viral infections (18). Wichmann et al. reported that croup syndrome was slightly increased in children living on streets with a high traffic load (19). In a study by Schwartz et al. the incidence of croup increased by $27 \%$ when the concentration of the total suspended particulate matter increased from $10 \mu \mathrm{g} / \mathrm{m}^{3}$ to $70 \mu \mathrm{g} / \mathrm{m}^{3}$, while the same increase in $\mathrm{NO}_{2}$ levels resulted in a $28 \%$ increase in cases (20). In Teplice and Prachatice children, there was no association of the occurrence of LT with previous acute exposure to PAHs or $\mathrm{PM}_{2.5}$ (7). In children living in the district of Teplice, the RR of LT for interquartile increase of 14-day-long mean exposure to $\mathrm{NO}_{\mathrm{x}}$ was 1.24 (95\% CI $1.03-1.37)$ in children under 2 and 1.20 (95\% CI 1.00-1.45) in older children (21). The analysis controlled for confounding by indoor pollutants, ETS (environmental tobacco smoke), season, and the type of heating used in the flat. An important source of $\mathrm{NO}_{\mathrm{x}}$ is traffic, which increases with the degree of urbanization. Thus, high levels of $\mathrm{NO}_{\mathrm{x}}$ in an urban environment could contribute to the high incidence rate of LT in the town of Teplice. On the other hand, Levy et al. reported that personal exposure to $\mathrm{NO}_{\mathrm{x}}$ correlates more with its indoor than outdoor levels, and that a dominant 
indoor source of $\mathrm{NO}_{2}$ is a gas oven (22). A document from WHO states that the use of gas ovens increases indoor $\mathrm{NO}_{2}$ to levels associated with an increase of lower respiratory infections by $20 \%$ (23). When the monitoring station in Teplice was moved from the town centre to the periphery, it was found that the highest levels of $\mathrm{NO}_{2}$ were associated with south and west winds, which means that the transport of $\mathrm{NO}_{2}$ from industrial sources in the district contributes to outdoor levels of $\mathrm{NO}_{2}$ in TE-town (24).

Otitis media is considered the most common infection of early childhood. This is not the case of children living in the district of Teplice or Prachatice. It is also not the case of children living in the city of Ostrava (Czech Republic), where a relatively low incidence of OM peaks in the 4th or 5th year of life, when more than $50 \%$ children started to attend day-care (25). Rovers et al. evaluated risk factors for otitis media from "an international perspective" using a survey of published data. They concluded that the main environmental risk factors for otitis media were day-care, the number of siblings, smoking, breastfeeding, birth weight, socio-economic status, and air pollution (26). However, Heinrich and Raghuyamshi in their review stated that although some studies reported a statistically significant increased risk for otitis media in children with high exposure to ambient air pollutants, the risks were not consistent among the studies (27). In fact, other studies suggest a number of further risk factors. In the above-mentioned study in the city of Ostrava, the risk factors were caesarean section, newborn icterus with phototherapy and the presence of gas appliances in the household (25). In the present study there is no doubt about a higher incidence rate of $\mathrm{OM}$ in the first four years of life of children from TE-town. The risk factors were a low birth weight and/or premature delivery, the presence of an older sibling in the household and diagnosed allergic rhinitis. Influenza is caused by infection with influenza $A$ and $B$ viruses. It spreads in typical epidemics and reaches peak prevalence in winter. Influenza diagnosis is clinical (28). In our lists of illnesses two ICD-10 codes were used: J10-Influenza due to identified influenza virus (31 diagnoses) and J11-Influenza, virus not identified (1,879 diagnoses). It may be difficult to distinguish between the common cold and influenza in the early stages of these infections. Thus, some cases of influenza may be diagnosed as upper respiratory infections. Brauer et al. reported an association of traffic-related air pollution and an increased risk of serious flu/serious colds in children during the first 4 years of life (29). The high occurrence of influenza in the town of Teplice may also be due to the high density of inhabitants, which facilitates the spread of the disease.

Our definition of the group of upper respiratory infections is narrower than that used in other reports. The diagnosis of common cold (J00) represents $26 \%$ of the URI group diagnoses in TE-town and $15 \%$ in PRA. Most cases of the common cold are mild and symptoms disappear within a week. Nevertheless, some children can be at risk of complications. Sinusitis (J01) was diagnosed extremely rarely. Acute pharyngitis (J02) was diagnosed in 46\% of the URI group in TE-town and 24\% in PRA. The code J06 (upper respiratory infections of multiple and unspecified locations) was used in $26 \%$ and $55 \%$ of URI diagnoses in TE-town and PRA, respectively. The relative frequencies of illnesses per 100 children in all 10 years of follow-up show that URI represented $50 \%, 45 \%$ and $33 \%$ of all diagnoses in PRA, TE-district and TEtown, respectively. The yearly incidences of URI in PRA were higher than in the other two regions of residence from the 4th year of life (Fig. 1). The high prevalence of allergic rhinitis (adjusted OR $1.5,95 \%$ CI 1.1-1.9) in PRA and older siblings with allergy partly contributes to the high incidence of URI in the district of Prachatice (AR: adjusted RR 1.5, 95\% CI 1.1-1.9, sibling with allergy: adjusted RR 1.3, 95\% CI 1.1-1.7). In other studies, an association of URI with pollutant levels was proven for cases that required hospital admission and the association between increased admissions/visits to emergency rooms and increased levels of pollutants was stronger in infants $(<1$ year) than in older preschool children (30-33). Thus, our finding of a higher incidence of URI in a rural environment is rather unexpected.

The incidence of bronchitis in the youngest and preschool children (more precisely, in the first five years) was highest in children living in the district of Prachatice (paediatricians in the Czech Republic do not distinguish between bronchitis and bronchiolitis). In the multivariate model, the maternal education level and age over 30 were the most significant determinants of the incidence of bronchitis, and most of the previously recognized factors (ETS exposure, gender, having older siblings etc.) were also significantly associated with the incidence of bronchitis. None of these factors confounded the effects of the region of residence on the incidence of bronchitis. Inevitably, children diagnosed with LT decrease the pool of children that could be diagnosed with bronchitis. The children (older than 3 years) with allergic rhinitis in PRA had a higher risk of bronchitis (RR 1.4, $p=0.007,95 \%$ CI 1.1-1.9) adjusted for maternal education, the type of flat, an older sibling with an allergy and positive skin tests to pollen. Hertz-Picciotto et al. have shown that in Prachatice and Teplice children under 4.5 years of age (there were no data for older ages at the time of analysis), the occurrence of bronchitis increased with the increasing concentration of PAHs or $\mathrm{PM}_{2.5}$ in the previous seven days (7). In the same cohort of children under 2 in the district of Teplice the RR of bronchitis for interquartile increase of $\mathrm{NO}_{\mathrm{x}}$ concentration in the past 3 days was $1.09(95 \%$ CI 1.01-1.16) (21).

The incidence of pneumonia was, in the first three years, highest in children living in TE-town. We do not have information whether all diagnoses were confirmed radiologically in nonhospitalized children. In studies using hospital admission records, it has been shown that a significant increase in daily admissions for pneumonia was related to increased levels of several pollutants including $\mathrm{O}_{3}, \mathrm{NO}_{2}, \mathrm{PM}_{10}$, and $\mathrm{PM}_{2.5}$ (30-33). In our study, the increased incidence of pneumonia in TE-town children was significant only in the $0-2$ y age category.

Literature data on the incidence of tonsillitis is rather scarce. According to the largest study based on 165.3 million ambulatory health care visits of children under 15 in 1993-95 (data from the U.S. National Survey) the principal diagnosis of sore throat and tonsillitis (including a streptococcal sore throat) had an incidence of 18.1 per 100 children per year (34), which was less than middle ear infections (35.2/100) and cold, cough and runny nose (24.2/100). In our recent study of children born and living for 6 years in the city of Ostrava (Czech Republic), the incidence of tonsillitis in a heavily polluted part of the city was 78 per 100 children per year and 19.2 per 100 children per year in less polluted parts of the city (35). In contrast, in the present study the incidence of tonsillitis in the first three years of life was lowest in children living in the town of Teplice. 
The data on allergies were obtained in 2005. However, in 2008 the coordinated international research on bronchial asthma in children led to new recommendations for both the diagnosis and treatment of asthma in children under five (36). For this reason we are using the term "wheezing". This diagnosis was more frequent in the polluted district of Teplice after limiting the comparisons to children of Czech ethnicity. The higher percentage of children sensitized to pollen and, consequently, the higher prevalence of allergic rhinitis in the district of Prachatice is, in our opinion, due to genetic predisposition and greater exposure to pollen in the rural environment. However, we have not differentiated between pollinosis and other forms of allergic rhinitis.

What are the strengths and limitations of the study? The study was based on the extensive cooperation of paediatricians and paediatric nurses in both districts. The families were contacted and asked to take part in the study by a paediatrician/nurse whom they knew and trusted, thus refusal to participate in the study was rare. The data on the morbidity of children were obtained from paediatric records, thus the diagnoses and their dates were recorded at the time of illness. Since the records of visits to specialists or to a hospital are forwarded to the paediatrician, we have data on all illnesses of the children. All paediatricians in the study area participated, which minimized the possibility of selection bias. The use of ICD-coded diagnoses diminished errors due to the different approaches of the nearly 50 paediatricians taking part in the study. A validity study of paediatric diagnostic practice was conducted with good results (7). The limitation of this longitudinal study is the insufficient data on the real exposure of the children to pollutants. The pollutant data came from just one station in each district, and neither dispersion models nor GIS files with traffic data (for instance) and the children's home addresses were used. In particular, the concentrations of $\mathrm{PM}_{10}$ and $\mathrm{NO}_{2}$ may differ throughout the districts due to the location of sources, geographical factors, the level of urbanization, and the meteorological situation. The smaller particles, $\mathrm{PM}_{2.5}$ and PAHs, behave differently, and it appears that their distribution throughout the districts is more or less homogenous, except distribution at higher altitudes.

\section{CONCLUSIONS}

The prevalence of allergic rhinitis and the incidence rates of bronchitis (from the 1st to 4th year of life) and of upper respiratory infections (from the 4th to 10th year of life) were highest in children living in the rural district of Prachatice. The occurrence of otitis media might be associated with industrial pollution of the district of Teplice. In the first two years of life, the children living in the urban environment of TE-town as well as children living in an industrial environment of TE-district had a significantly higher incidence of otitis media than children living in the rural district of Prachatice. A frequent occurrence of laryngitis/ tracheitis in children was characteristic of the urban environment of the town of Teplice. The incidence rates of laryngitis/tracheitis and influenza in TE-town persisted as the highest among the three regions since birth till the age of 10 years. Thus, the three regions we have compared differed in spectra of respiratory illnesses but not in the overall respiratory morbidity of children. The total cumulative incidence of respiratory illnesses per 100 children per
10 years was almost the same in the district of Prachatice and in TE-town and 10\% lower in TE-district. In TE-town there were $17 \%$ fewer diagnoses of upper respiratory infections and $18 \%$ more diagnoses of laryngitis/tracheitis and influenza than in the district of Prachatice.

\section{Acknowledgement}

The study was supported by the Ministry of Environment of the Czech Republic (VaV/340/1/1997, VaV/340/2/00, VaV/740/5/03, VaV-1C/6/5/04, SL-5/160/05, SP/1b3/8/08). The authors deeply appreciate the participation of Prof. I. Hertz-Picciotto, University of California Davis, and of her co-workers as well as financial support from the Health Effects Institute, Boston, MA, USA (HEI-01-3). Special thanks go to Dr. Rakesh Ghosh for critical comments and advice on statistics. The study would not have been possible without the close cooperation of all paediatricians and paediatric nurses in both districts.

\section{Conflict of Interests}

None declared

\section{REFERENCES}

1. Donnelly KC. Children, health and their environment. In: Donnelly KC, Cizmas LH, editors. Environmental health in Central and Eastern Europe. Dordrecht: Springer; 2006. p. 221-30.

2. Dejmek J, Selevan SG, Beneš I, Solanský I, Šrám RJ. Fetal growth and maternal exposure to particulate matter during pregnancy. Environ Health Perspect. 1999 Jun;107(6):475-80.

3. Šrám RJ, Binková B, Dejmek J, Bobak M. Ambient air pollution and pregnancy outcomes: a review of the literature. Environ Health Perspect. 2005 Apr;113(4):375-82.

4. Hertz-Picciotto I, Herr CEW, Yap PS, Dostál M, Shumway RH, Ashwood $\mathrm{P}$, et al. Air pollution and lymphocyte phenotype proportions in cord blood. Environ Health Perspect. 2005 Oct;113(10):1391-8.

5. Herr CEW, Dostal M, Ghosh R, Ashwood P, Lipsett M, Pinkerton KE, et al. Air pollution exposure during critical time periods in gestation and alterations in cord blood lymphocyte distribution: a cohort of livebirths. Environ Health. 2010 Aug 2;9:46.

6. Herr CEW, Ghosh R, Dostal M, Skokanova V, Ashwood P, Lipsett M, et al. Exposure to air pollution in critical prenatal time windows and IgE levels in newborns. Pediatr Allergy Immunol. 2011 Feb;22(1 Pt 1):75-84.

7. Hertz-Picciotto I, Baker RJ, Yap PS, Dostál M, Joad JP, Lipsett M, et al. Early childhood lower respiratory illness and air pollution. Environ Health Perspect. 2007 Oct;115(10):1510-8.

8. Baker RJ, Hertz-Picciotto I, Dostál M, Keller JA, Nožička J, Kotěšovec $\mathrm{F}$, et al. Coal home heating and environmental tobacco smoke in relation to lower respiratory illness in Czech children, from birth to 3 years of age. Environ Health Perspect. 2006 Jul;114(7):1126-32.

9. Hertz-Picciotto I, Topinka J, Dostal M, Joad JP, Yap PS, Greenfield T, et al. XPD gene polymorphisms, air pollution, and bronchitis in early childhood. Epidemiology. 2006 Nov; 17(6 Suppl):S25.

10. Ghosh R, Topinka J, Joad JP, Dostal M, Sram RJ, Hertz-Picciotto I. Air pollutants, genes and early childhood acute bronchitis. Mutat Res. 2013 Sep;749(1-2):80-6.

11. Schmuczerova J, Brdicka R, Dostal M, Sram RJ, Topinka J. Genetic variability of HVRII mtDNA in cord blood and respiratory morbidity in children. Mutat Res. 2009 Jun 18;666(1-2):1-7.

12. Dostál M, Hertz-Picciotto I, James R, Keller J, Dejmek J, Selevan S, et al. Childhood morbidity and air pollution in the Teplice program. Cas Lek Cesk. 2001 Oct 25;140(21):658-61.

13. Berk R, MacDonald J. Overdispersion and poisson regression [Internet]. University of Pennsylvania; 2007 [cited 2014 Mar 18]. Available from: http://www.udel.edu/soc/faculty/parker/SOCI836_S08_files/ Berk\&MacDonald JQCF.pdf.

14. Greenland S. Modeling and variable selection in epidemiologic analysis. Am J Public Health. 1989 Mar;79(3):340-9. 
15. Dostal M, Topinka J, Sram RJ. Comparison of the health of Roma and non-Roma children living in the district of Teplice. Int J Public Health. 2010 Oct;55(5):435-41.

16. von Mutius E, Nicolai T, Lehmacher W, Reitmeir P, Stiepel E. Are there risk factors for stenosing laryngitis? Results of the Southern Bavaria pseudo-croup study. Monatsschr Kinderheilkd. 1989 Nov;137(11):71621. (In German.)

17. Severien C, Mietens C. Effect of nitrogen oxides and suspended dust in the air on the incidence of inpatient treatment of children with stenosing laryngotracheitis (pseudocroup). Results of an 8-year epidemiologic retrospective study based on inpatient case figures and area-related data of air measurements in the Bochum city district. Monatsschr Kinderheilkd. 1987 Oct;135(10):686-91. (In German.)

18. Rebmann H, Huenges R, Wichmann HE, Malin EM, Hübner HR, Röll A, et al. Croup and air-pollution: results of a two-years prospective longitudinal study. Zentralbl Hyg Umweltmed. 1991 Sep;192(2):104-15. (In German.)

19. Wichmann HE, Hübner HR, Malin E, Köhler B, Hippke G, Fischer D, et al. The significance of health risks caused by outdoor pollution, demonstrated by cross-sectional studies of pseudocroup in Baden-Württemberg. Offentl Gesundheitswes. 1989 Aug-Sep;51(8-9):414-20. (In German.)

20. Schwartz J, Spix C, Wichmann HE, Malin E. Air pollution and acute respiratory illness in five German communities. Environ Res. 1991 Oct;56(1):1-14

21. Ghosh R, Joad J, Benes I, Dostal M, Sram RJ, Hertz-Picciotto I. Ambient nitrogen oxides exposure and early childhood respiratory illnesses. Environ Int. 2012 Feb;39(1):96-102.

22. Levy JI, Lee K, Spengler JD, Yanagisawa Y. Impact of residential nitrogen dioxide exposure on personal exposure: an international study. J Air Waste Manag Assoc. 1998 Jun;48(6):553-60.

23. Nitrogen dioxide. In: WHO guidelines for indoor air quality: selected pollutants. Copenhagen: WHO Regional Office for Europe; 2010. p. 201-87.

24. Beneš I, Skorkovský J, Novák J, Šrám RJ. Air pollution in Prague, Teplice and Prachatice in the last 15 years. Comparison of data and discussion on changes and trends. Ochrana ovzduší. 2010;(5-6):18-23. (In Czech.)

25. Dostál M, Pastorková A, Lochmanová A, Šrám RJ. Incidence of otitis media in children living in heavy polluted environment. Ochrana ovzduší. 2012;(5):20-5. (In Czech.)
26. Rovers MM, de Kok IM, Schilder AG. Risk factors for otitis media: an international perspective. Int J Pediatr Otorhinolaryngol. 2006 Jul;70(7):1251-6.

27. Heinrich J, Raghuyamshi VS. Air pollution and otitis media: a review of evidence from epidemiologic studies. Curr Allergy Asthma Rep. 2004 Jul;4(4):302-9.

28. Worrall G. Influenza. Can Fam Physician. 2008 Mar;54(3):415-6.

29. Brauer M, Hoek G, Smit HA, de Jongste JC, Gerritsen J, Postma DS, et al. Air pollution and development of asthma, allergy and infections in a birth cohort. Eur Respir J. 2007 May;29(5):879-88.

30. Barnett AG, Williams GM, Schwartz J, Neller AH, Best TL, Petroeschevsky AL, et al. Air pollution and child respiratory health: a casecrossover study in Australia and New Zealand. Am J Respir Crit Care Med. 2005 Jun 1;171(11):1272-8.

31. Gouveia N, Fletcher T. Respiratory diseases in children and outdoor air pollution in São Paulo, Brazil: a time series analysis. Occup Environ Med. $2000 \mathrm{Jul} ; 57(7): 477-83$

32. Ilabaca M, Olaeta I, Campos E, Villaire J, Tellez-Rojo MM, Romieu I. Association between levels of fine particulate and emergency visits for pneumonia and other respiratory illnesses among children in Santiago, Chile. J Air Waste Manag Assoc. 1999 Sep;49(9 Spec No):154-63.

33. Peel JL, Tolbert PE, Klein M, Metzger KB, Flanders WD, Todd K, et al. Ambient air pollution and respiratory emergency department visits. Epidemiology. 2005 Mar;16(2):164-74.

34. Freid VM, Makuc DM, Rooks RN. Ambulatory health care visits by children: principal diagnosis and place of visit. Vital Health Stat 13. 1998 May;(137):1-23.

35. Dostál M, Pastorková A, Rychlík Š, Švecová V, Rychlíková E, Šrám RJ. Morbidity of children in Ostrava 2001 - 2009. Ochrana ovzduší. 2011;(56):7-12. (In Czech.)

36. Bacharier LB, Boner A, Carlsen KH, Eigenmann PA, Frischer T, Götz M, et al.; European Pediatric Asthma Group. Diagnosis and treatment of asthma in childhood: a PRACTALL consensus report. Allergy. 2008 Jan;63(1):5-34.

Received August 29, 2013 Accepted in January 31, 2014 